\title{
Location and Vascular Classification of 188 parathyroid glands in New Zealand White Rabbits
}

\author{
[Localização e Classificação Vascular de 188 glândulas paratireoidianas em \\ coelhos brancos da Nova Zelândia] \\ W. Cao ${ }^{\#}$, Y. Su ${ }^{\#}$, N. Liu, Y. Peng, C. Diao, R. Cheng*
}

First Affiliated Hospital of Kunming Medical University - Kunming - Yunan, China

\begin{abstract}
The function and protection of the parathyroid glands are increasingly popular research topics. New Zealand white rabbits are the most commonly used animal model of parathyroid ischemia. However, information on the vasculature of their parathyroid glands is limited. We used 94 healthy New Zealand white rabbits, 3-4 months of age and 2-3kg in weight, for exploration of the parathyroid glands, which were stained using hematoxylin and eosin (HE) after removal. The following types were classified according to the relationship between the position of the inferior parathyroid gland and the thyroid: Type A, Close Type, Type B, and Distant Type. There were 188 cases, 4 where the inferior parathyroid glands were located near the dorsal side of thyroid $(2.13 \%), 8$ where the inferior parathyroid glands were located superior to the upper pole of the thyroid (4.26\%), 20 where the inferior parathyroid glands were located parallel to the thyroid $(10.64 \%)$, and 155 cases where the inferior parathyroid glands were located inferior to the lower pole of thyroid (82.45\%). Identifying the location and classifying the vasculature of the parathyroid glands in New Zealand white rabbits will provide an anatomical model to assist in future research.
\end{abstract}

Keywords: New Zealand white rabbits, parathyroid glands, blood supply types

\section{RESUMO}

A função e proteção das glândulas paratireoidianas é um tópico de pesquisa cada vez mais popular. Coelhos brancos da Nova Zelândia são o modelo animal mais comumente usada para isquemia da paratireóide. Porém, informação sobre a vasculatura de suas glândulas paratireóides é limitada. Foram usados 94 coelhos brancos da Nova Zelândia saudáveis, com 3-4 meses de idade, 2-3kg de peso, para exploração das glândulas paratireóides, que foram coradas com hematoxilina e eosina (HE) após a remoção. Os seguintes tipos foram classificados de acordo com a relação entre a posição da glândula paratireoidiana inferior e a tireoide: Tipo A, Tipo Próximo, Tipo B e Tipo Distante. Houve 188 casos, 4 em que as glândulas paratireoidianas inferiores estavam localizadas próximas ao lado dorsal da tireoide (2.13\%), 8 onde as glândulas paratireoidianas inferiores estavam localizadas superiores ao polo superior da tireoide (4.26\%), 20 onde as glândulas paratireoidianas inferiores estavam localizadas paralelo à tireoide (10.64\%) e 155 casos em que as glândulas paratireoidianas inferiores estavam localizadas inferiores ao polo inferior da tireoide (82.45\%). A identificação da localização e a classificação da vasculatura das glândulas paratireóides em coelhos brancos da Nova Zelândia fornecerão um modelo anatômico para auxiliar em pesquisas futuras.

Palavras-chave: coelho branco da Nova Zelândia, glândulas paratireóides, tipos de suprimento de sangue

Recebido em 12 de outubro de 2019

Aceito em 24 de março de 2020

*Autor para correspondência (corresponding author)

E-mail: cruochuan@foxmail.com

\#Wei-han Cao and Yan-jun Su contributed equally to this study 


\section{INTRODUCTION}

The parathyroid glands are indispensable organs of the endocrine system whose main function is to regulate calcium-phosphorus metabolism. Severe impairment of the parathyroid glands may lead to hypocalcemia (Gardella and Vilardaga, 2015). Chief cells are the most prevalent cells in the human parathyroid glands. Secretion of parathyroid hormone (PTH), which is regulated by receptors on chief cells, control calciumphosphorus metabolism and the secretion of calcitonin and 1,25-dihydroxyvitamin $\mathrm{D}$ by thyroid gland C-cells (Gardella and Vilardaga, 2015). The New Zealand white rabbit is the most common ischemic parathyroid animal model used for research on the function and protection of the parathyroid glands owing to the complex vascular distribution and a great variation of their parathyroid glands, which resemble human parathyroid glands. Anatomical descriptions of the New Zealand white rabbit are available, although there is little information available on their parathyroid blood vessels. We describe the location and blood supply types of 188 parathyroid glands of New Zealand white rabbits.

\section{MATERIAL AND METHODS}

With approval from the Animal Management Committee of Kunming Medical University, 94 (47 male and 47 female) healthy New Zealand white rabbits between 3 and 4 months of age and weighing between 2 and $3 \mathrm{~kg}$ were selected. The rabbits were humanely killed using an intravenous injection with $3 \%$ sodium pentobarbital solution $(1 \mathrm{~mL} / \mathrm{kg})$ in the margin of the ear. The $3 \%$ sodium pentobarbital solution was purchased from the First Affiliated Hospital of Kunming Medical University.

The anesthetized rabbits were immobilized in a supine and head-back position. Fur was removed from the surgical site and the area was disinfected with iodophor three times to avoid contamination. Using cricoid cartilage as an anatomical landmark, a $4 \mathrm{~cm}$ longitudinal incision was made starting $1 \mathrm{~cm}$ from the head and extending to $3 \mathrm{~cm}$ from the foot. The skin was cut, followed by the subcutaneous tissue, and anterior cervical muscle. The linea alba cervicalis was disconnected and the trachea was exposed.
The lower parathyroid gland was exposed, and its blood vessels were identified in the following areas: the superior and inferior cricoid cartilage, on the peripheral and dorsal side of the thyroid, in the tracheoesophageal groove, and between the sternothyroid muscle and scapula. After the exploration, the parathyroid gland was removed and preserved in $4 \%$ paraformaldehyde solution. Hematoxylin and eosin (HE) staining was performed after sectioning of the paraffinembedded tissues. All surgical and experimental procedures were approved by the Ethics Committee of Kunming Medical University (No. Kmmu2019056) and performed in accordance with the guidelines enacted by the National Laboratory Animal Management Regulations .

\section{RESULTS}

The location of the parathyroid glands in 188 New Zealand white rabbits were as follows: near the dorsal side of the thyroid, $2.13 \%$ (4 cases); superior to the upper pole and distal from the thyroid, $4.26 \%$ (8 cases); parallel and distal from the thyroid, $10.64 \%$ (20 cases); inferior to the lower pole and distal from the thyroid, $82.45 \%$ (155 cases); and posterior to the sternum, $0.53 \%$ ( 1 case). The distribution of parathyroid glands in rabbits is not symmetrical, but they are located on approximately the same level.

The six parathyroid glands located near the thyroid were completely symmetrical. The parathyroid glands posterior to the sternum and on the contralateral side (lower pole and distal from the thyroid) possessed the greatest variation in position among rabbits. The parathyroid glands were located at the horizontal position of the thyroid or at the lower pole of the thyroid and distal to the thyroid, the tracheoesophageal groove, between the sternothyroid muscle and scapula, or around the carotid sheath (all close to the common carotid artery).

The relationship of the inferior parathyroid gland to the thyroid in New Zealand white rabbits was classified as follows (Table 1): Type A and Close Type, proximal the thyroid; Type B and Distant Type, distal the thyroid. Type B, bound by the horizontal area of the thyroid, was classified into subtypes: Type B1, the upper pole of the thyroid above the horizontal area; Type B2, the horizontal area of thyroid; Type B3, the lower pole of thyroid below the horizontal area. 
According to the location of parathyroid gland, Type B can be classified into five types: Type $\mathrm{BI}$, located in tracheoesophageal groove; Type BII, located between sternothyroid muscle and scapula; Type BIII, located around the carotid sheath; Type BIV, located in the thymi posterior to the sternum; and Type BV encompasses for all other locations.

Table 1. Classification based on location of Parathyroid glands in New Zealand White Rabbits

\begin{tabular}{|c|c|c|c|c|}
\hline \multicolumn{2}{|c|}{ Types } & Location of parathyroid gland & Quantity & Percentage \\
\hline Type & A & Close to the thyroid gland & 4 & $2.13 \%$ \\
\hline Type & $\mathrm{B}$ & Far away from the thyroid gland & 184 & $97.87 \%$ \\
\hline & B1 & - at the upper pole of thyroid above the horizontal area & 8 & $4.26 \%$ \\
\hline & $\mathrm{B} 2$ & - at the horizontal area of thyroid & 20 & $10.64 \%$ \\
\hline & B3 & - at the lower pole of thyroid below the horizontal area & 155 & $82.45 \%$ \\
\hline & BI & - in tracheal esophageal groove & 28 & $14.89 \%$ \\
\hline & BII & - between sternum thyroid muscle and scapula & 76 & $40.43 \%$ \\
\hline & BIII & - around carotid sheath & 50 & $26.56 \%$ \\
\hline & BIV & - in the thymus area behind the sternum & 1 & $0.53 \%$ \\
\hline & BV & - other locations & 0 & $0 \%$ \\
\hline
\end{tabular}

The blood supply for the inferior parathyroid artery in 8 of 188 cases $(4.26 \%)$ came from the superior thyroid artery and in 180 of 188 cases $(95.74 \%)$ came from the common carotid artery. The blood supply for the parathyroid artery in Type A comes from the superior thyroid artery, and for Type BIII the blood supply comes from the common carotid artery.

New Zealand white rabbits have substantial variation in the number of blood vessels in their
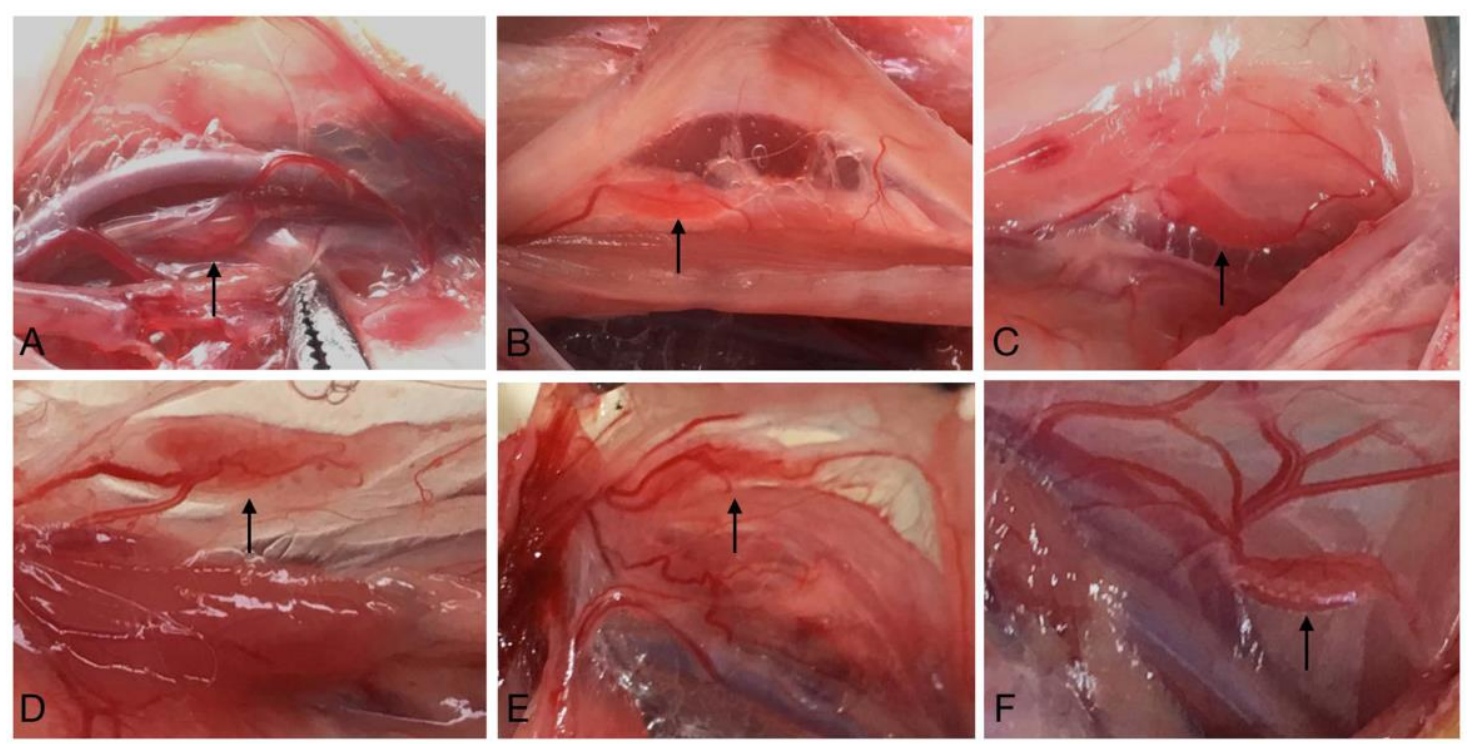

Figure 1. Typing of parathyroid blood in New Zealand white rabbits (according to the number of blood vessels visible to the naked eye). The black arrow points: parathyroid glands. A: $1 / 1+X$ blood vessels for blood supply. B: 2 blood vessels for blood supply. C: $2+\mathrm{X}$ blood vessels for blood supply. D: 3 blood vessels for blood supply. E: 3+X blood vessels for blood supply. F: 4/4+X blood vessels for blood supply. 
There are many blood vessels surrounding the parathyroid glands of New Zealand white rabbits, although not all of these supply blood to the parathyroid gland (Figure 2A). The parathyroid glands of the rabbits may be encapsulated by fat sacs, and the blood supply for the fat cells composing these sacs are supplied by the blood vessels that supply the thyroid (Figure 2B). HE staining confirmed the inferior parathyroid gland was composed of chief cells (Figure 3).
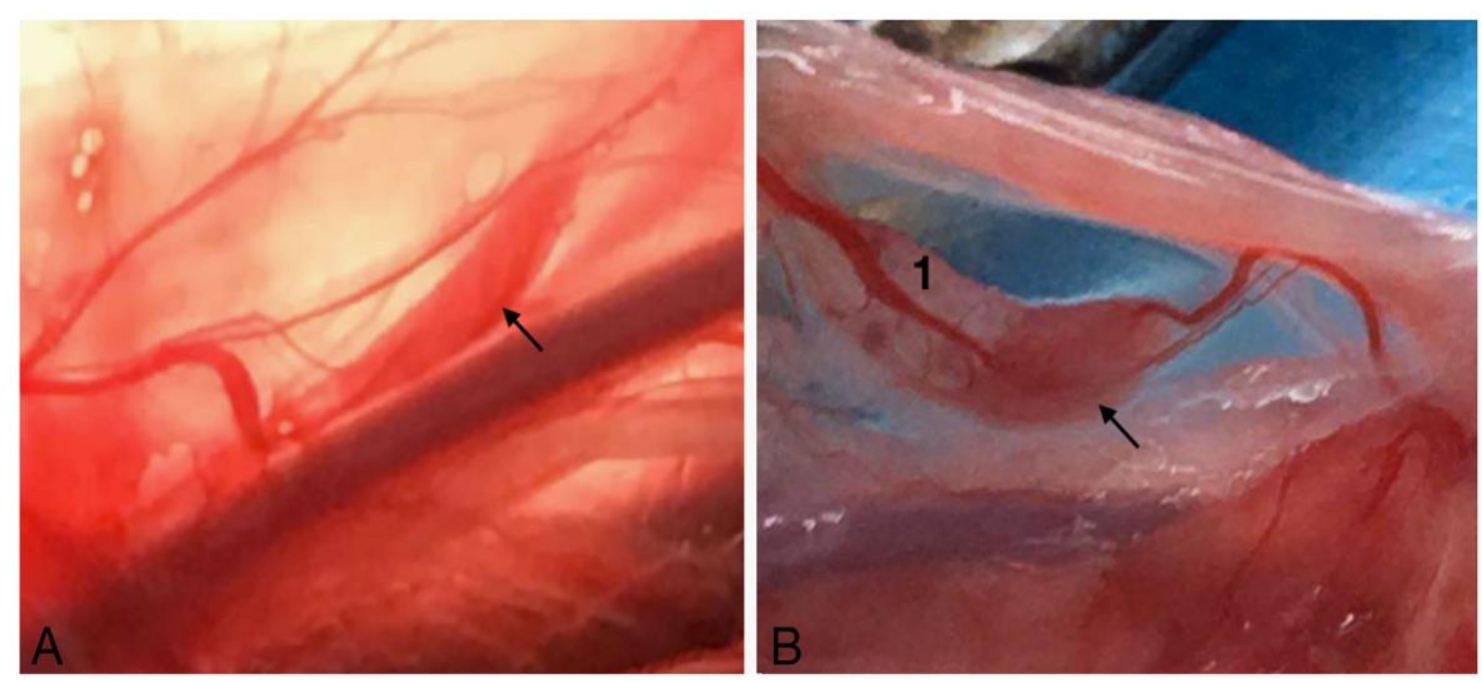

Figure 2. Fat sac of parathyroid glands and its blood supply. A: Not all the blood vessels around the parathyroid gland flow into the parathyroid gland. B: The parathyroid glands of New Zealand white rabbits can be encapsulated by fat sacs. The black arrow: parathyroid gland. 1: adipose capsule.

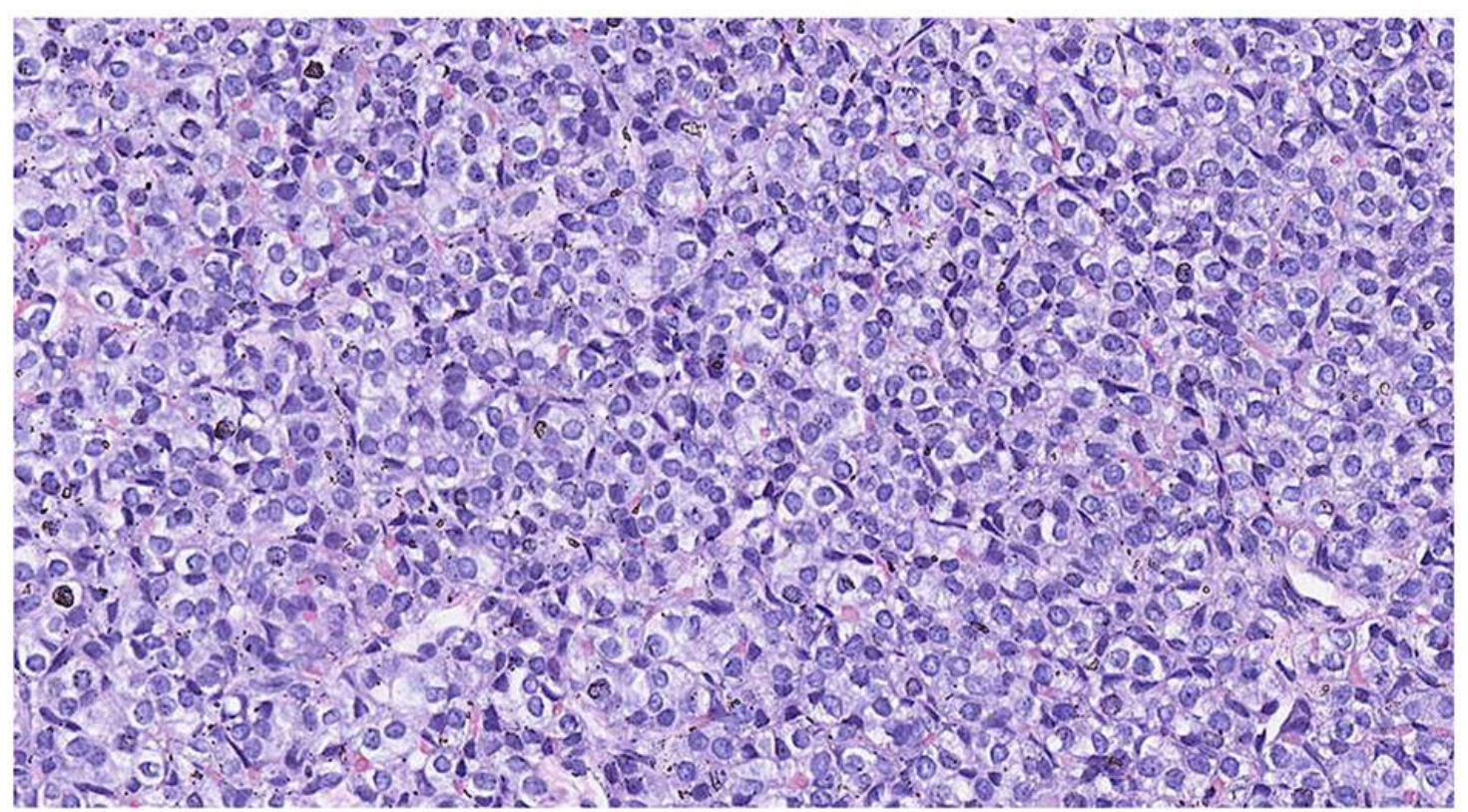

Figure 3. HE staining result of inferior parathyroid gland of New Zealand white rabbits $(\times 400)$.

\section{DISCUSSION}

Generally, the inferior parathyroid glands of New Zealand white rabbits are oval or spindle- shaped glands weighing approximately $0.01 \mathrm{~g}$, located dorsal to the thyroid, attached to both sides of the trachea at the foot of the thyroid artery (Antakia et al., 2014). These glands are 
red, soft, and easily observable (Antakia et al., 2014). Rabbits, have four parathyroid glands and their superior parathyroid gland is located in the thyroid (Shoumura et al., 1993). Tan hypothesized that there were only four parathyroid glands in rabbits and that the bilateral inferior parathyroid glands were located in the fascial space surrounded by the common carotid artery, sternothyroid muscle, and thyrohyoid muscle (Ritter et al., 2012), which was confirmed by our observations.

Ectopic parathyroid glands occur more frequently in humans than in rabbits. The majority of the inferior parathyroid glands are located near the lower third of the thyroid, anterior to the recurrent laryngeal nerve, anterior to the lower thyroid surface or within $1 \mathrm{~cm}$ from the side rear (Tan et al., 1987). Wang (1976) dissected 645 parathyroid glands from 160 cadavers and concluded that the inferior parathyroid glands were located in the thyrothymic ligament, anterior or proximal the trachea, or in the sternothyroid muscle (Wang, 1976). The parathyroid may also be located anterior to the mediastinum or thymus and inferior to the aortic arch, pulmonary artery, or aortic sulcus.

The locations of parathyroid glands are similar in rabbits and humans. Most parathyroid glands are located around the dorsal side of the thyroid between the tracheoesophageal groove, sternothyroid, and omohyoid. However, there are some differences between human and rabbits. In humans, more inferior parathyroid glands are located in the lower third of the thyroid gland $(50 \%)$, and in rabbits, parathyroid glands are located posterior the thyroid $(1.06 \%)$.

The human inferior parathyroid artery is believed to originate from the inferior thyroid artery. The location and blood supply of human parathyroid glands can be divided into Types I-III. Inferior parathyroid arteries of all types are separated from the inferior thyroid arteries ( $\mathrm{Su}$ et al., 2018). The inferior parathyroid arteries in New Zealand white rabbits generally originate from the common carotid artery $(95.74 \%)$ or the superior thyroid artery $(4.26 \%)$. It is believed that during embryonic development the parathyroid glands develop from the dorsal portion of the pharyngeal sac of the lateral pharyngeal wall. The thyroid develops from the pharynx and migrates to its current position in the adult body (Merida-Velasco et al., 1999).

Different migration processes may be responsible for the differences in the location and the origin of blood supply for the parathyroid glands in rabbits and humans. The parathyroid gland has its own arterial blood supply; although two or more arteries may travel to the parathyroid gland, only one artery supplies blood. The other arteries supply blood to the fat cells surrounding the parathyroid glands. This observation has been made in rabbits. The difference may be because of multiple parathyroid arteries in rabbits. The artery supplying blood to the fat sacs surrounding the parathyroid glands may also supply blood to the thyroid. Damage to the arteries and veins of the parathyroid glands affect the blood supply to the gland, and the arteries and veins are not easy to differentiate by the naked eye; therefore, we did not distinguish between arteries and veins in this study. The parathyroid glands of rabbits consist of chief cells and differ from that of humans owing to their lack of eosinophils (Ritter et al., 2012).

\section{CONCLUSION}

We proposed an anatomical model and vascular classification system for the parathyroid glands of New Zealand white rabbits to assist in future modeling and studies.

\section{ACKNOWLEDGEMENTS}

The panel recognizes the contributions of $\mathrm{Na}$ Zhou, Shanghai, China for her outstanding logistical support during our study. The study was supported by National Natural Science Foundation of China (Grant No.: 81760142), Association Foundation Program of Yunnan Science and Technology Department and Kunming Medical University (Grant NO.:2018FE001(-168)), and Scientific Research Fund of Yunnan Education Department (Grant NO.: 2019J1248).

\section{REFERENCES}

ANTAKIA, R.; GAYET, P.; GUILLERMET, S. et al. Near infrared fluorescence imaging of rabbit thyroid and parathyroidglands. J. Surg. Res., v.192, p.480-486, 2014. 
GARDELLA, T.J.; VILARDAGA, J.P. International Union of Basic and Clinical Pharmacology. XCIII. The parathyroid hormone receptors--family $\mathrm{Bg}$ protein-coupled receptors. Pharmacol. Rev., v.67, p.310-337, 2015.

MERIDA-VELASCO, J. A.; SÁNCHEZMONTESINOS, I.; ESPÍN-FERRA, J. et al. Ectodermal ablation of the third branchial arch in chick embryos and the morphogenesis of the parathyroid IIIgland. J. Craniofac. Dev. Biol., v.19, p.33-40, 1999.

RITTER, C.S.; HAUGHEY, B.H.; BROWN, B.M.A.J. Differentialgene expression by oxyphil and chief cells of human parathyroidglands. $J$. Clin. Endocrinol. Metab., v.97, p.E1499-E1505, 2012.
SHOUMURA, S.; EMURA, S.; ISONO, H. The parathyroidgland under normal and experimental conditions. Kaibogaku Zasshi, V.68, p.5-29, 1993.

SU, A.; GONG, Y.; WEI, T. et al. A new classification of parathyroidglands to evaluate in situ preservation or autotransplantation during thyroid surgery. Medicine, v.97, p.e13231, 2018.

TAN, S.Q.; JAO, W.; THOMAS, D. et al. Surgical thyroparathyroidectomy of the rabbit. Am. J. Physiol., v.252, p.F761-F767, 1987.

WANG, C. The anatomic basis of parathyroid surgery. Ann. Surg., v.183, p.271-275, 1976. 